\title{
PROFIL KEMANDIRIAN BELAJAR MAHASISWA BIMBINGAN DAN KONSELING
}

\author{
Budi Astuti \\ Program Studi Bimbingan dan Konseling, Universitas Negeri Yogyakarta \\ e-mail: budi_astuti@uny.ac.id
}

\begin{abstract}
Abstrak
Penelitian ini bertujuan untuk mengetahui profil kemandirian belajar mahasiswa Bimbingan dan Konseling di Universitas Negeri Yogyakarta. Profil kemandirian belajar mahasiswa dilihat berdasarkan jenis kelamin, usia, dan aspek kemandirian belajar. Jenis penelitian ini adalah penelitian kuantitatif dengan jenis pendekatan survei. Sampel penelitian sejumlah 248 mahasiswa program studi Bimbingan dan Konseling, Fakultas Ilmu Pendidikan, Universitas Negeri Yogyakarta. Teknik penentuan sampel menggunakan teknik random sampling. Metode pengumpulan data menggunakan kuesioner, yaitu skala kemandirian belajar. Hasil analisis data menunjukkan bahwa tingkat kemandirian belajar mahasiswa sebagian besar berada pada kategori sedang sejumlah 209 mahasiswa (84,3\%). Berdasarkan jenis kelamin dan usia, sebagian besar tingkat kemandirian mahasiswa berada pada kategori sedang. Berdasarkan aspek kemandirian belajar, ditemukan bahwa aspek motivasi dalam belajar merupakan aspek tertinggi dengan nilai rata-rata 731, aspek yang kedua adalah aspek perilaku dalam belajar dengan nilai rata-rata 689 dan aspek yang ketiga adalah aspek pemahaman belajar dengan nilai rata-rata 680. Penelitian ini memberikan rekomendasi agar kemandirian belajar mahasiswa dapat dioptimalkan dengan peningkatan strategi regulasi belajar dan dukungan dari pihak universitas.
\end{abstract}

Kata Kunci: kemandirian belajar, mahasiswa, bimbingan dan konseling

\section{PROFILE OF SELF REGULATED LEARNING ON STUDENTS OF GUIDANCE AND COUNSELING}

\begin{abstract}
The study aimed to determine the profile of self regulated learning on students of Guidance and Counseling at Yogyakarta State University. The profile of students' self regulated learning assessed based on gender, age, and aspects of self regulated learning. The research type was quantitative research with a survey approach. The sample was 248 students of the Guidance and Counseling study program, Faculty of Education, Yogyakarta State University. The sampling technique used random sampling techniques. The data collection method was a questionnaire, which was the scale of self regulated learning. The results of data analysis showed that the level of student's self regulated learning was mostly in the moderate category with 209 students (84,3\%). Based on gender and age, most levels of student's self regulated learning were in the moderate category. The aspect of self regulated learning found out that the motivation in learning was the highest aspect with an average score of 731, followed by behavior in learning with an average score of 689 and learning understanding with an average score of 680. The particular study proposed recommendations the student's self regulated learning could be optimized by improving the learning regulation strategy and support from the university.
\end{abstract}

Keywords: self regulated learning, students, guidance and counseling 


\section{PENDAHULUAN}

Universitas Negeri Yogyakarta merupakan sebuah institusi pendidikan tinggi yang memberikan gelar akademik dalam berbagai bidang. Universitas berfungsi untuk mencetak generasi intelektual dengan berbagai kompetensi yang dimilikinya. Mahasiswa di bawah naungan universitas berusaha untuk mengeksplorasi kemampuan dan potensi diri baik secara akademik maupun non akademik. Mahasiswa Universitas Negeri Yogyakarta dituntut untuk berpikir kreatif dan inovatif sehingga tercipta sosok unggul yang bertaqwa, mandiri, dan cendekia.

Salah satu tantangan terbesar bagi universitas pada masa kini dan masa mendatang ialah fasilitasi kompetensi mahasiswa agar memiliki kemandirian dalam belajar. Kesiapan mahasiswa dalam menempuh pendidikan di universitas, salah satunya adalah belajar mandiri. Hal inilah yang membedakan kultur akademik antara jenjang pendidikan sekolah dasar dan menengah dengan pendidikan tinggi. Mahasiswa dituntut untuk mandiri dalan segala hal, termasuk dalam bidang belajar atau akademik. Ilmu pengetahuan yang diperoleh dari bangku kuliah terasa sangat minim dibandingkan dengan luasnya ilmu dari berbagai referensi. Oleh karena itu, mahasiswa tidak cukup belajar di dalam kelas, namun juga perlu belajar secara mandiri di luar kelas.

Menurut sudut pandang pendidikan, kemandirian belajar menyiratkan kapasitas yang dimiliki mahasiswa dalam proses mengatur dirinya sendiri dalam kegiatan belajar. Kapasitas pengaturan diri sendiri tersebut memainkan peranan penting dalam mencapai kesuksesan di universitas. Kemandirian belajar didefinisikan sebagai sebuah sistem sosio-kognitif yang kompleks, dimanifestasikan dalam tingkatan yang berbeda dan kontrol terhadap proses belajar dalam diri seseorang, termasuk di dalamnya meliputi: kemampuan, kapasitas, sikap, pengambilan keputusan terhadap pilihan-pilihan, perencanaan, dan tindakan dalam belajar (Chitashvili, 2007). Definisi tersebut mengandung makna yang sangat dinamis. Sebagai sistem yang kompleks, kemandirian seseorang sangat bergantung pada dorongan untuk bertanggungjawab yang dimiliki seseorang dalam aktivitas belajarnya. Hal ini erat hubungannya dengan strategi metakognisi mulai dari perencanaan, pengambilan keputusan hingga monitoring dan evaluasi. Demikian halnya menurut penjelasan Valle et al. (2008) bahwa kemadirian belajar merupakan sebuah proses yang secara aktif mendorong mahasiswa untuk menetapkan tujuan, memimpin mahasiswa untuk belajar, memonitor, mengatur dan mengendalikan kognisi, motivasi dan perilaku untuk mencapai tujuan. Kesuksesan belajar di universitas merupakan tujuan yang akan dicapai oleh mahasiswa melalui kemampuan dan motivasi individu untuk memonitor diri dan mengendalikan emosi, pikiran, dan tindakan (Ellis \& Helaire, 2018).

Pada kenyataannya, setiap mahasiswa memiliki tingkat kemandirian belajar yang berbeda-beda. Sebagian mahasiswa menunjukkan kemandirian belajar yang sangat baik, namun sebagian mahasiswa lainnya menunjukkan kemandirian belajar yang tidak baik. Sebagaimana didukung oleh Moos \& Ringdal (2012) bahwa setiap mahasiswa memiliki perbedaan individu dalam cara belajar. Perbedaan inidividu nampak pada tidak hanya apa yang dipelajari mahasiswa, tetapi juga bagaimana proses belajar mahasiswa.

Beberapa penelitian yang relevan terkait gambaran kemandirian belajar peserta didik telah dilakukan. Abun \& Magallanes (2018) menemukan bahwa kemandirian belajar peserta didik tergolong tinggi. Hal ini ditandai dengan pengaturan diri akademik peserta didik yang tinggi. Di sisi lain, hasil observasi peneliti pada dua tahun terakhir pada mahasiswa program studi bimbingan dan konseling FIP UNY, diperoleh adanya perilaku belajar mahasiswa yang berbeda-beda. Ada yang tertarik dengan kelas dan ada yang tidak tertarik. Hal ini dapat dilihat melalui partisipasi mahasiswa dalam diskusi kelas. Beberapa mahasiswa antusias untuk belajar dan 
mengekspresikan ide-ide mereka tetapi ada juga yang tidak. Beberapa termotivasi tetapi beberapa tidak termotivasi, mereka tampaknya tidak peduli dengan diskusi kelas.

Selanjutnya, sebuah penelitian membuktikan bahwa sebagian besar mahasiswa yang telah mencapai studi pada jenjang yang lebih tinggi, tidak cukup siap untuk menghadapi apa yang harus dilakukan di universitas. Hal ini disebabkan karena mahasiswa tidak dapat mengatur proses kemandirian pada diri sendiri. Hal ini mengakibatkan kurangnya strategi dan proses pengaturan diri dianggap sebagai faktor utama yang menyebabkan kegagalan dalam menempuh pendidikan di universitas (Valle et al., 2008). Dari paparan riset-riset tersebut, banyak faktor yang mempengaruhi tingkat kemandirian belajar seorang mahasiswa. Faktor-faktor dari dalam diri individu maupun faktor dari luar individu menjadi penentu mahasiswa agar termotivasi untuk menunjukkan sikap mandiri dalam belajar.

Keberagaman temuan penelitian terdahulu, tidak dapat digunakan untuk membuat kesimpulan terkait profil kemandirian belajar mahasiswa. Sementara itu, kemandirian belajar merupakan unsur penting bagi mahasiswa sebagai faktor penunjang keberhasilan dan kesuksesan studi di universitas. Oleh karena itu, perlu dilakukan sebuah penelitian yang bertujuan untuk mengetahui profil kemandirian belajar mahasiswa Bimbingan dan Konseling, Fakultas Ilmu Pendidikan, Univeritas Negeri Yogyakarta.

\section{METODE}

Jenis penelitian ini adalah penelitian kuantitatif dengan jenis penelitian survei. Pengumpulan data penelitian dilakukan pada bulan Mei sampai dengan Juli 2017. Lokasi penelitian bertempat di Program Studi Bimbingan dan Konseling FIP UNY. Sampel penelitian yang dilibatkan dalam penelitian ini adalah mahasiswa strata satu Bimbingan dan Konseling FIP UNY sejumlah 248 mahasiswa. Teknik penentuan sampel menggunakan random sampling.
Instrumen yang digunakan dalam penelitian ini adalah skala kemandirian belajar. Skala kemandirian belajar ini menggunakan empat alternatif jawaban: sangat sesuai (SS), sesuai (S), tidak sesuai (TS) dan sangat tidak sesuai (STS). Validasi yang digunakan adalah validasi konten. Pada validasi konten ini, instrumen dikonstruksi dari aspek-aspek yang akan diukur dengan berlandaskan teori dan kemudian dikonsultasikan dengan para ahli (expert judgment).

Analisis data yang dilakukan pada penelitian ini adalah: a) pemberian skor pada jawaban sampel, b) menjumlahkan skor total masing-masing aspek, c) mengelompokkan skor yang diperoleh dari sampel berdasarkan tingkat kecenderungan. Penskoran dalam penelitian ini berdasarkan skala yaitu 4,3,2,1 untuk item favourable dan 1,2,3,4 untuk item unfavourable. Setelah dilakukan analisis penskoran pada jawaban, langkah selanjutnya adalah melakukan uji rerata pada hasil jumlah skor jawaban. Hasil rerata yang telah dianalisis diterjemahkan ke dalam beberapa kelompok kategori.

\section{HASIL DAN PEMBAHASAN Hasil}

Penelitian ini melibatkan 248 mahasiswa program studi bimbingan dan konseling sebagai sampel penelitian. Klasifikasi sampel penelitian terdiri dari kelompok berdasarkan jenis kelamin (lakilaki dan perempuan) dan usia (19-23 tahun). Berikut ini secara lengkap disajikan tabel tentang klasifikasi sampel yang terlibat dalam penelitian.

Tabel 1. Klasifikasi Sampel Penelitian

\begin{tabular}{llr}
\hline $\begin{array}{l}\text { Klasifikasi } \\
\text { Sampel }\end{array}$ & Kelompok & Jumlah \\
\hline Jenis Kelamin & Laki-laki & 44 \\
& Perempuan & 204 \\
& 19 tahun & 102 \\
Usia & 20 tahun & 79 \\
& 21 tahun & 53 \\
& 22 tahun & 8 \\
& 23 tahun & 6 \\
\hline
\end{tabular}


Berdasarkan hasil analisis data penelitian diketahui bahwa sebagian besar mahasiswa program studi bimbingan dan konseling FIP UNY memiliki tingkat kemandirian belajar pada kategori sedang. Hal ini diketahui berdasarkan hasil penentuan norma kemandirian belajar sebagai berikut.

Tabel 2. Penentuan Norma Kemandirian Belajar

\begin{tabular}{cccc}
\hline Interval & Kategori & Jumlah & $\%$ \\
\hline$>170$ & Tinggi & 39 & 15,7 \\
$113-169$ & Sedang & 209 & 84,3 \\
$56-112$ & Rendah & 0 & 0 \\
\hline
\end{tabular}

Dari perhitungan pengkategorisasian di atas didapatkan hasil bahwa sebanyak 39 mahasiswa $(15,7 \%)$ memiliki tingkat kemandirian belajar tinggi. Sementara itu, 209 mahasiswa $(84,3 \%)$ berada dalam kategori sedang dalam kemandirian belajarnya dan tidak ada satu pun mahasiswa yang berada dalam kategori rendah. Jadi dapat disimpulkan bahwa sebagian besar mahasiswa program studi bimbingan dan konseling FIP UNY memiliki kemandirian belajar pada kategori sedang.

Hasil analisis data berdasarkan jenis kelamin menunjukkan bahwa terdapat 6 mahasiswa laki-laki $(2,4 \%)$ berada pada kategori tinggi dan 38 mahasiswa laki-laki $(15,3 \%)$ berada pada kategori sedang. Selanjutnya untuk kelompok perempuan terdapat 33 mahasiswa $(13,3 \%)$ berada pada kategori tinggi dan 171 mahasiswa (69\%) berada pada kategori sedang. Nilai rata-rata kemandirian belajar kelompok laki-laki adalah 156,25 dan nilai rata-rata kelompok perempuan adalah 159,64 .

Tabel 3. Klasifikasi Kemandirian Belajar Berdasarkan Jenis Kelamin

\begin{tabular}{llrrr}
\hline $\begin{array}{l}\text { Jenis } \\
\text { Kelamin }\end{array}$ & Kategori & Jumlah & $\begin{array}{c}\text { Rata- } \\
\text { rata }\end{array}$ \\
\hline \multirow{3}{*}{ Laki-laki } & Tinggi & 6 & 2,4 & \\
& Sedang & 38 & 15,3 & 156,25 \\
& Rendah & 0 & 0 & \\
\hline \multirow{3}{*}{ Perempuan } & Tinggi & 33 & 13,3 & \\
& Sedang & 171 & 69 & 159,64 \\
& Rendah & 0 & 0 & \\
\hline
\end{tabular}

Dari tabel di atas, diketahui bahwa nilai rata-rata kemandirian belajar mahasiswa perempuan lebih tinggi dibandingkan kemandirian belajar mahasiswa laki-laki. Oleh karena itu, dapat disimpulkan bahwa kemandirian belajar mahasiswa perempuan lebih tinggi dibandingkan kemandirian belajar mahasiswa laki-laki.

Berdasarkan kategori usia, dilihat bahwa pada kelompok usia 19 tahun terdapat 20 mahasiswa $(8,1 \%)$ berada pada kategori tinggi dan 82 mahasiswa $(33,1 \%)$ berada pada kategori sedang. Selanjutnya pada kelompok usia 20 tahun terdapat 11 mahasiswa $(4,4 \%)$ berada pada kategori tinggi dan 68 mahasiswa $(27,4 \%)$ berada pada kategori sedang. Pada kelompok usia 21 tahun, terdapat 8 mahasiswa $(3,2 \%)$ berada pada kategori tinggi dan 45 mahasiswa $(18,1 \%)$ berada pada kategori sedang. Berikutnya pada kelompok usia 22 tahun, terdapat 8 mahasiswa $(3,2 \%)$ berada pada kategori sedang. Profil terakhir pada kelompok usia 23 tahun terdapat 6 mahasiswa $(2,4 \%)$ berada pada kategori sedang. Nilai rata-rata kelompok usia 19 tahun adalah 163,31, kelompok usia 20 tahun adalah 157,47, kelompok usia 21 tahun adalah 154,81, kelompok usia 22 tahun adalah 152,25, kelompok usia 23 tahun adalah 153,5.

Tabel 4. Klasifikasi Kemandirian Belajar Berdasarkan Usia

\begin{tabular}{clrrr}
\hline $\begin{array}{c}\text { Usia } \\
\text { (Thn) }\end{array}$ & Kategori & Jumlah & $\%$ & $\begin{array}{c}\text { Rata- } \\
\text { rata }\end{array}$ \\
\hline \multirow{3}{*}{19} & Tinggi & 20 & 8,1 & \\
& Sedang & 82 & 33,1 & 163,31 \\
& Rendah & 0 & 0 & \\
\hline \multirow{3}{*}{20} & Tinggi & 11 & 4,4 & \\
& Sedang & 68 & 27,4 & 157,47 \\
& Rendah & 0 & 0 & \\
\hline \multirow{3}{*}{21} & Tinggi & 8 & 3,2 & \\
& Sedang & 45 & 18,1 & 154,81 \\
& Rendah & 0 & 0 & \\
\hline \multirow{2}{*}{22} & Tinggi & 0 & 0 & \\
& Sedang & 8 & 3,2 & 152,25 \\
& Rendah & 0 & 0 & \\
\hline \multirow{2}{*}{23} & Tinggi & 0 & 0 & \\
& Sedang & 6 & 2,4 & 153,5 \\
& Rendah & 0 & 0 & \\
\hline
\end{tabular}


Tabel 4 menggambarkan bahwa nilai rata-rata kemandirian belajar mahasiswa pada kelompok usia termuda justru memiliki nilai rata-rata kemandirian belajar tertinggi dibandingkan kelompok usia lain yang lebih tua. Oleh karena itu, dapat disimpulkan bahwa kemandirian belajar mahasiswa usia muda lebih tinggi dibandingkan kemandirian belajar mahasiswa usia lebih tua.

Selanjutnya klasifikasi kemandirian belajar berdasarkan aspek kemandirian belajar, dideskripsikan bahwa aspek motivasi adalah aspek tertinggi dengan nilai rata-rata 731 , yang kedua adalah aspek perilaku dengan nilai rata-rata 689 dan terakhir adalah aspek kognitif dengan nilai rata-rata 680.

Tabel 5. Klasifikasi Kemandirian Belajar Berdasarkan Aspek-Aspeknya

\begin{tabular}{llc}
\hline Aspek & Kategori & Rata-rata \\
\hline Motivasi & Tinggi & 731 \\
Perilaku & Sedang & 689 \\
Kognitif & Rendah & 680 \\
\hline
\end{tabular}

Dari tabel di atas, menunjukkan bahwa jika dilihat dari nilai rata-rata kemandirian belajar mahasiswa berdasarkan aspek kemandirian belajar, aspek motivasi lebih tinggi dibandingkan aspek kemandirian belajar yang lain. Oleh karena itu, dapat disimpulkan bahwa aspek motivasi dari kemandirian belajar lebih banyak mempengaruhi kemandirian belajar mahasiswa program studi bimbingan dan konseling FIP UNY jika dibandingkan dengan aspek kemandirian belajar yang lain, yaitu aspek perilaku dan aspek kognitif.

Lebih lanjut jika ditinjau berdasarkan indikator masing-masing aspek kemandirian belajar, dapat dilihat pada tabel berikut ini.
Tabel 6. Klasifikasi Kemandirian Belajar Berdasarkan Indikator-indikatornya

\begin{tabular}{|c|c|c|c|c|}
\hline Aspek & Indikator & Kategori & $\begin{array}{l}\text { Rata } \\
\text {-rata }\end{array}$ & $\%$ \\
\hline \multirow[t]{3}{*}{ Kognitif } & $\begin{array}{l}\text { Latihan/pengula } \\
\text { ngan }\end{array}$ & & 664 & 75 \\
\hline & Elaborasi & & 698 & \\
\hline & $\begin{array}{l}\text { Meregulasi } \\
\text { metakognitif }\end{array}$ & & 639 & \\
\hline \multirow[t]{6}{*}{ Motivasi } & $\begin{array}{l}\text { Penguasaan self- } \\
\text { talk }\end{array}$ & & 711 & \\
\hline & $\begin{array}{l}\text { Kemampuan } \\
\text { relatif self-talk }\end{array}$ & & 706 & \\
\hline & Peningkatan & & 653 & \\
\hline & $\begin{array}{l}\text { minat terhadap } \\
\text { situasi }\end{array}$ & Rendah & & 71,4 \\
\hline & $\begin{array}{l}\text { Konsekuensi } \\
\text { intrinsik }\end{array}$ & & 716 & \\
\hline & $\begin{array}{l}\text { Penataan } \\
\text { lingkungan }\end{array}$ & & 697 & \\
\hline \multirow[t]{2}{*}{ Perilaku } & $\begin{array}{l}\text { Meregulasi } \\
\text { usaha }\end{array}$ & & 639 & \\
\hline & $\begin{array}{l}\text { Mengatur waktu } \\
\text { dan tempat } \\
\text { belajar }\end{array}$ & & 704 & 67 \\
\hline Kognitif & $\begin{array}{l}\text { Pengorganisasia } \\
\mathrm{n}\end{array}$ & & 717 & 25 \\
\hline Motivasi & $\begin{array}{l}\text { Ekstrinsik self- } \\
\text { talk }\end{array}$ & Sedang & 763 & 14,3 \\
\hline Perilaku & $\begin{array}{l}\text { Mencari } \\
\text { bantuan }\end{array}$ & & 724 & 33 \\
\hline Motivasi & $\begin{array}{l}\text { Peningkatan } \\
\text { yang relevan }\end{array}$ & Tinggi & 870 & 14,3 \\
\hline
\end{tabular}

Hasil analisis menunjukkan bahwa indikator latihan/pengulangan, elaborasi dan meregulasi metakognitif dari aspek kognitif, indikator penguasaan self-talk, kemampuan relatif self-talk, peningkatan minat terhadap situasi, konsekuensi intrinsik dan penataan lingkungan dari aspek motivasi, serta indikator meregulasi usaha dan mengatur waktu dan tempat belajar dari aspek perilaku berada pada kategori rendah. Selanjutnya indikator pengorganisasian dari aspek kognitif, indikator ekstrinsik self-talk dari aspek motivasi dan indikator mencari bantuan dari aspek perilaku berada pada kategori sedang. Sementara itu, indikator peningkatan yang relevan dari aspek motivasi berada pada kategori tinggi. 
Berdasarkan tabel hasil klasifikasi kemandirian belajar menurut indikator di atas, diketahui bahwa $75 \%$ aspek kognitif berada pada kategori rendah dan $25 \%$ pada kategori sedang. Selanjutnya aspek motivasi berada pada kategori rendah sebesar 71,4\%, 14,3\% pada kategori sedang dan 14,3\% berada pada kategori tinggi. Pada aspek perilaku sebesar 67\% berada pada kategori rendah dan $33 \%$ berada pada kategori sedang. Jadi dapat disimpulkan bahwa hanya aspek motivasi pada kemandirian belajar mahasiswa yang memiliki nilai rata-rata tinggi pada indikatornya.

\section{Pembahasan}

Hasil penelitian ini terbagi menjadi beberapa temuan sesuai dengan tujuan penelitian yaitu untuk mengetahui kemandirian belajar mahasiswa. Temuan penelitian yang utama ialah profil kemandirian belajar mahasiswa program studi bimbingan dan konseling FIP UNY. Temuan penelitian berikutnya ialah profil kemandirian belajar berdasarkan jenis kelamin, usia, aspek-aspek dan indikator-indikator dari kemandirian belajar. Pembahasan temuan penelitian tersebut dijelaskan berikut ini.

Temuan penelitian utama ditemukan bahwa sebagian besar mahasiswa program studi bimbingan dan konseling FIP UNY memiliki kemandirian belajar pada kategori sedang. Hasil ini berbeda dengan temuan penelitian dari Abun \& Magallanes (2018) menemukan bahwa kemandirian belajar peserta didik tergolong tinggi. Kategori tinggi tersebut ditandai dengan pengaturan diri akademik peserta didik yang tinggi. Mestinya mahasiswa dapat meningkatkan kemandirian belajarnya sehingga mendapatkan banyak manfaat. Sebagaimana diungkapkan oleh Harding (2018) bahwa mahasiswa dapat memperoleh manfaatmanfaat ketika dapat mengatur diri sendiri dalam pembelajarannya. Mahasiswa mendapat manfaat dari penggunaan perilaku mandiri dalam belajar untuk bertahan dari masalah yang menantang. Masalah tersebut ditemukan solusinya sehingga mencapai kesuksesan dan kepuasan atas upaya pemecahan masalahnya. Ketika mahasiswa menjadi lebih aktif dan bertanggung jawab dalam pembelajarannya, mahasiswa menetapkan tujuan untuk dirinya sendiri, menyelesaikan tugas yang diharapkan dan meninjau kembali pekerjaan mereka untuk menentukan apa yang telah dipelajari. Ketika mahasiswa mengatur pembelajarannya sendiri, mereka dapat meningkatkan kemandirian dan kecakapan. Mahasiswa dapat semakin mengembangkan, mengadaptasi dan mengakses peluang belajar di luar yang dibayangkan oleh dosen mereka.

Beberapa pendekatan dan strategi untuk belajar mandiri dikemukakan oleh Harding (2018) meliputi; a) pengamatan, dalam hal ini mahasiswa mengamati proses yang dimodelkan oleh orang lain, deskripsi verbal, bimbingan, dan umpan balik, b) peniruan dan praktik, dalam hal ini mahasiswa meniru perilaku belajar yang diatur sendiri, c) internalisasi, dalam hal ini mahasiswa menggunakan strategi secara mandiri, d) perekaman, dalam hal ini mahasiswa mencatat strategi yang berhasil dan memantau kemajuan, e) pemantauan, dalam hal ini mahasiswa (dan dosen) merefleksikan penggunaan strategi dan mengendalikan perilaku masa depan yang sesuai. Inti dari strategi ini adalah kesadaran mahasiswa dan keterlibatan yang disengaja untuk belajar mandiri.

Lebih lanjut, mahasiswa yang menemukan permasalahan, beban tugas, dan tantangan belajar yang lebih kompleks seringkali dituntut untuk memiliki tingkat kemandirian yang lebih tinggi. Mahasiswa yang mandiri akan terampil dalam mengatur strategi belajarnya secara sistematis, dan secara mandiri akan memenuhi tuntutan perubahan situasi baik pribadi maupun kontekstual. Rekomendasi yang diberikan dosen untuk mendukung pengembangan keterampilan kemandirian belajar antara lain (Harding, 2018): 1) membangun kepercayaan diri mahasiswa, menetapkan tujuan dan harapan dalam; mengembangkan bidang keilmuan, mendiskusikan strategi belajar mandiri secara spesifik, pemodelan atau instruksi dalam strategi 
belajar mandiri, 2) menyediakan akses pada dialog reflektif (termasuk strategi untuk self-talk atau berbicara sendiri), 3) memberikan umpan balik yang bersifat korektif, 4) membantu mahasiswa mengembangkan strategi untuk membangun hubungan pada konsep-konsep abstrak, 5) membantu mahasiswa untuk menghubungkan pengalaman baru dengan pembelajaran sebelumnya secara otomatis, dan 6) mengharuskan mahasiswa untuk merefleksikan, mengevaluasi, mencatat strategi dan proses yang berhasil untuk memitigasi strategi yang gagal.

Kemandirian belajar mahasiswa yang dipromosikan oleh dosen, mendorong mahasiswa untuk memastikan bahwa tugas belajar mereka sepenuhnya telah dipahami. Tugas belajar dipilih sesuai tingkat kesulitannya, kemudian tugas dilaksanakan sesuai rencana dan strategi yang efektif untuk menyelesaikannya. Hal ini berguna untuk memantau kemajuan pribadi. Lingkungan belajar yang bersifat konvensional dapat dimodifikasi dengan penerapan pembelajaran yang berbasis pada teknologi informasi dan digilatisasi. Hasil penelitian Johnson \& Davies (2014) menegaskan bahwa mahasiswa yang difasilitasi dengan dukungan pembelajaran berbasis teknologi informasi dan digilatisasi dibandingkan dengan mereka yang tidak, menunjukkan peningkatan signifikan pada kemandirian belajarnya (misalnya ditinjau dari perencanaan, penyusunan strategi, dan pemantauan).

Penelitian Sebesta \& Speth (2017) mengemukakan bahwa mahasiswa yang berprestasi lebih tinggi, dan meraih peningkatan nilai hasil belajar (IPK) pada semester awal, dilaporkan lebih sering menggunakan strategi kognitif dan metakognitif spesifik secara signifikan daripada rekan-rekan mereka yang berprestasi rendah. Mahasiswa dengan prestasi yang lebih rendah, dilaporkan bahwa mereka tidak menerapkan strategi yang direncanakan atau jika mereka melakukannya, masih belum dapat meningkatkan hasil belajar. Hasil ini menunjukkan bahwa banyak mahasiswa yang memiliki pengetahuan terbatas tentang strategi pengaturan diri dalam belajar secara mandiri dan efektif. Keterbatasan kemampuan untuk mengimplementasikan strategi pengaturan diri dalam belajar secara efektif, dapat mempengaruhi pencapaian hasil belajar. Pengembangan strategi pengaturan diri dalam belajar secara mandiri dan efektif direkomendasikan sebagai alat pedagogis yang integral dan ditujukan untuk mendorong mahasiswa dalam pengembangan keterampilan belajar sepanjang hayat.

Kemandirian belajar berdasarkan variabel moderator (usia dan jenis kelamin) memberikan hasil yang signifikan. Hal ini senada dengan hasil penelitian Aydin et al. (2017) menunjukkan bahwa usia, jenis kelamin, dan kelas memiliki perbedaan signifikan pada kecemasan belajar bidang bahasa. Diperkuat oleh Mohammadi et al. (2015) bahwa terdapat hubungan signifikan antara usia dan jenis kelamin dengan gaya belajar pada mahasiswa. Senada pula dengan hasil penelitian Corbin (2017) bahwa terdapat perbedaan signifikan antara usia dan gender dengan gaya belajar mandiri. Gaya belajar mandiri merupakan prediktor signifikan dari prestasi akademik mahasiswa. Mahasiswa yang memiliki kemandirian belajar yang tinggi, lebih dominan meraih Grade Point Averages (IPK) yang lebih tinggi, sedangkan mahasiswa yang sebaliknya lebih dominan meraih IPK yang lebih rendah.

Temuan penelitian menunjukkan bahwa kemandirian belajar mahasiswa perempuan lebih tinggi dibandingkan kemandirian belajar mahasiswa laki-laki. Temuan penelitian ini mendukung beberapa hasil riset sebelumnya yang menyatakan bahwa kemandirian belajar berdasarkan jenis kelamin perempuan lebih mengungguli laki-laki (Matthews, Cameron, \& Moriison, 2009), anak laki-laki lebih rendah kemampuan dan prestasi bidang matematika dan kemampuan regulasi diri dibandingkan dengan anak perempuan (Weis, Heikamp, \& Tromsdorff, 2013).

Hasil penelitian didukung oleh Studenska (2011) melakukan penelitian 
yang bertujuan untuk mengetahui tingkat kesulitan belajar pada pria dan wanita dari berbagai tingkat pendidikan berbeda. Sejumlah 380 orang berpartisipasi dengan mengisi instrumen kesulitan belajar. Hasil penelitian menunjukkan bahwa kesulitan dalam perencanaan, pengorganisasian dan pelaksanaan pembelajaran berpengaruh signifikan ditinjau dari gender dan tingkat pendidikan. Perbedaan gender terbukti berpengaruh signifikan terhadap kesulitan dalam motivasi, kontrol emosional, refleksi dan perubahan perilaku. Mahasiswa lakilaki perlu mendapat dukungan dosen dalam perencanaan, kontrol motivasi dan keterampilan refleksi.

Hasil penelitian diketahui bahwa kemandirian belajar mahasiswa usia muda lebih tinggi dibandingkan kemandirian belajar mahasiswa usia lebih tua. Temuan penelitian ini senada dengan Usher \& Pajares (2008) mengemukakan hasil penelitian yaitu peserta didik pada jenjang pendidikan yang lebih rendah memiliki keyakinan diri akan kemandirian belajar lebih tinggi dibandingkan peserta didik pada jenjang pendidikan yang lebih tinggi. Dari penelitian tersebut, dapat dianalogikan bahwa mahasiswa yang lebih muda memiliki kemandirian belajar yang lebih tinggi daripada mahasiswa yang lebih tua.

Hasil penelitian menemukan bahwa aspek motivasi lebih banyak mempengaruhi kemandirian belajar mahasiswa program studi bimbingan dan konseling FIP UNY jika dibandingkan dengan aspek kemandirian belajar yang lain, yaitu aspek perilaku dan aspek kognitif. Pembahasan mengenai aspek-aspek kemandirian belajar mahasiswa diperkuat dengan pendapat Zimmerman (1989) kemandirian belajar merupakan cara seseorang membangun pikiran, perasaan, strategi, dan perilaku yang diorientasikan ke arah pencapaian tujuan belajar. Zimmerman menjabarkan kemandirian belajar meliputi tiga aspek yaitu: Aspek pertama yaitu kognitif yang meliputi latihan/pengulangan, elaborasi, pengorganisasian, dan metakognisi. aspek tersebut dijelaskan dalam beberapa strategi yaitu: a) strategi pengulangan (rehearsal) termasuk usaha untuk mengingat materi dengan cara mengulang terus menerus, b) strategi elaborasi (elaboration) merefleksikan "deep learning" dengan mencoba untuk meringkas materi dengan menggunakan kalimatnya sendiri, c) strategi organisasi (organization) termasuk "deep process" dalam melalui penggunaan taktik bervariasi seperti mencatat, menggambar diagram atau bagan untuk mengorganisasi materi pelajaran dalam beberapa cara, dan d) strategi meregulasi metakognitif (metacognition regulation) termasuk perencanaan, monitoring dan strategi meregulasi belajar, seperti menentukan tujuan dari kegiatan membaca, memonitoring suatu pemahaman atau membuat perubahan atau penyesuaian supaya ada kemajuan dalam tugasnya.

Aspek kedua yaitu motivasi yang meliputi penguasaan self-talk, ekstrinsik self-talk, kemampuan relative self-talk, peningkatan yang relevan, peningkatan minat terhadap situasi, konsekuensi intrinsik, penataan lingkungan. Aspek kedua tersebut dijelaskan dalam beberapa strategi yaitu: a) penguasaan self-talk adalah berpikir tentang penguasaan yang berorientasi pada tujuan seperti, memuaskan keingintahuan, menajdi lebih kompeten atau meningkatkan perasaan otonomi, b) ekstrinsik self-talk adalah ketika individu dihadapkan pada suatu keinginan untuk menyudahi proses belajar, individu akan berpikir untuk memperoleh prestasi yang lebih tinggi atau berusaha dengan baik di kelas sebagai cara meyakinkan diri mereka untuk terus melanjutkan kegiatan belajarnya, c) kemampuan relatif self-talk adalah saat individu berpikir tentang performa khusus untuk mencapai tujuan belajar, dengan cara melakukan usaha yang lebih baik daripada orang lain supaya tetap berusaha keras, d) strategi peningkatan yang relevan (relevance enhancement) melibatkan usaha individu untuk meningkatkan keterhubungan atau keberartian tugas dengan kehidupan atau minat personal yang dimiliki, e) strategi peningkatan minat situasional (situational interest enhancement) menggambarkan aktivitas 
individu ketika berusaha meningkatkan motivasi intrinsik dalam mengerjakan tugas melalui salah satu situasi atau minat pribadi, f) konsekuensi intrinsik adalah individu menetapkan dan menyiapkan untuk diri mereka dengan konsekuensi intrinsik supaya konsisten dalam aktivitas belajar. Individu dapat menggunakan reward dan punishment yang konkrit secara verbal sebagai wujud konsekuensi, dan g) strategi pengaturan lingkungan (environment structuring) menjelaskan usaha individu untuk berkonsentrasi penuh untuk mengurangi gangguan di lingkungan belajar mereka atau lebih umumnya untuk mengatur kesiapan fisik dan mental untuk menyelasaikan tugas akademis.

Aspek ketiga yaitu perilaku yang meliputi meregulasi usaha, mengatur waktu dan tempat belajar, dan mencari bantuan. Aspek ketiga dijelaskan dalam beberapa strategi yaitu: a) effort regulation adalah meregulasi usaha, b) time/study environment adalah individu mengatur waktu dan tempat dengan membuat jadwal belajar untuk mempermudah proses belajar, dan c) help-seeking adalah mencoba mendapatkan bantuan dari teman sebaya, dosen dan orang yang lebih senior.

Kemandirian belajar menggambarkan keterlibatan aktif mahasiswa dalam pembelajaran, termasuk menetapkan tujuan yang bermakna, memilih strategi spesifik yang sesuai terhadap penyelesaian tugas, pemantauan tingkat motivasi, dan adaptasi berdasarkan umpan balik. Keseluruhan hal positif tersebut terkait dengan hasil pembelajaran.

Fauzi \& Widjajanti (2018) menambahkan bahwa aspek yang memiliki pengaruh penting terhadap prestasi adalah motivasi. Mahasiswa dengan prestasi akademik yang tinggi cenderung memiliki yang motivasi kuat dalam bersaing dibandingkan dengan mahasiswa berprestasi rendah. Untuk mendapatkan prestasi yang lebih baik pada pendidikan saat ini tentunya tidak cukup hanya dengan belajar di universitas, karena kurikulum saat ini membutuhkan mahasiswa untuk belajar mandiri. Oleh karena itu, strategi pembe- lajaran di universitas diperlukan untuk mengembangkan kemampuan kognitif mahasiswa.

Di bidang pendidikan, belajar mandiri memiliki efek yang sangat signifikan dalam perkuliahan. Selain itu, lingkungan juga merupakan faktor yang mendukung pembelajaran mandiri melalui pemodelan, dorongan, fasilitas, penggunaan strategi yang baik dan proses lainnya. Belajar mandiri terbukti meningkatkan motivasi belajar mahasiswa sehingga dengan motivasi seperti itu, prestasi akademik mahasiswa dapat ditingkatkan. Sependapat dengan Mahmodi, Kalantari, dan Ghaslani (2014) yang menyatakan bahwa ada hubungan signifikan yang ditemukan antara motivasi dan Self Regulated Learning (SRL) atau kemandirian belajar. Motivasi mengharuskan mahasiswa untuk menerapkan strategi yang akan mempengaruhi proses pembelajaran. Mahasiswa akan cenderung lebih efisien mengatur waktu mereka dan menjadi efektif dalam pembelajaran jika motivasi mahasiswa tinggi. Dengan mengatur diri sendiri dalam belajar, mahasiswa menjadi mahir dalam mengatur pembelajaran mereka sendiri dan dapat meningkatkan hasil pembelajaran mereka.

Temuan penelitian yang terakhir diketahui bahwa hanya aspek motivasi pada kemandirian belajar yang memiliki nilai rata-rata tinggi pada indikatornya. Temuan penelitian ini sesuai dengan penelitian Kalenda \& Vávrová (2016) yang menjelaskan bahwa dimensi kognitif dan metakognitif pada kemandirian belajar mahasiswa dipengaruhi oleh motivasi sebagai kontributor tertinggi, selanjutnya pembelajaran dan manajemen waktu. Ketiganya melibatkan beragam implementasi dan refleksi terkait dengan pembelajaran. Pengelolaan pembelajaran, termasuk refleksi dan evaluasi oleh mahasiswa merupakan strategi dalam memobilisasi belajar. Emosi juga berperan dalam kemandirian belajar mahasiswa. Emosi ditemukan dalam tiga bentuk utama yaitu: 1) emosi terkait dengan studi mahasiswa, 2) emosi yang terkait dengan 
pembelajaran, dan 3) emosi yang terkait dengan ujian. Masing-masing jenis emosi ini berbeda tidak hanya pada asal usul emosi, tetapi juga pada arah keseluruhan emosi (emosi positif/negatif) dan intensitas emosi (intensitas tinggi/rendah).

Motivasi sebagai penunjang kemandirian belajar mahasiswa diperkuat dengan aplikasi dalam pembelajaran. Aplikasi diuraikan dalam satu model yang diadaptasi dari teori kemandirian belajar Zimmerman (Moos \& Ringdam, 2012) yang membagi tahapan pengaturan diri mahasiswa dalam belajar yang terdiri dari tiga fase, yaitu: pemikiran ke depan, kontrol kinerja, dan refleksi diri. Secara konkrit pada fase pertama yaitu pemikiran ke depan, mahasiswa "mengatur panggung" untuk tugas belajar yang akan datang. Mahasiswa yang mandiri akan mengembangkan harapan yang realistis, mengkreasikan tujuan dengan hasil spesifik, dan mengidentifikasi rencana untuk memaksimalkan kesuksesan dalam tugas belajar tertentu. Pada fase ini lah mahasiswa yang mandiri dapat mengajukan sendiri pertanyaan sebagai berikut; "Di mana tempat terbaik bagi saya untuk menyelesaikan tugas?", "Kondisi apa yang akan menciptakan tantangan bagi saya?", dan "Bagaimanakah saya memulai?". Pada fase kedua yaitu kontrol kinerja, merupakan proses-proses keterlibatan selama pembelajaran. Pada fase ini termasuk di dalamnya yaitu strategi spesifik seperti self-talk dan self-monitoring yang digunakan untuk memaksimalkan kesuksesan pada tugas belajar. Pertanyaan pada fase kedua bagi mahasiswa yang tergolong mandiri dapat ditanyakan pada diri mereka sendiri, antara lain; "Apakah saya menggunakan rencana saya dengan benar?", "Apakah saya mengalami hambatan atau kendala?", dan "Strategi apa yang bisa saya gunakan untuk membantu saya terus bekerja?" Pada fase terakhir, para mahasiswa yang mandiri melakukan perenungan pada akhir kegiatan pembelajaran. Evaluasi diri ini membandingkan hasil kinerja dengan tujuan. Mahasiswa yang mandiri dalam fase ini akan menanyakan pada diri mereka, pertanyaan seperti, "Apakah saya mencapai semua tujuan yang ditargetkan?", "Kondisi apa yang membantu saya menjadi sukses dan kondisi ada yang menghalangi kesuksesan?", dan "Strategi mana yang efektif dalam konteks dan kegiatan belajar?".

Ketiga fase yang telah diuraikan tersebut memberikan kontribusi yang signifikan terhadap kemandirian belajar mahasiswa. Hal ini diperkuat oleh Li et al. (2018) menyatakan temuan utama dari penelitian ini menunjukkan bahwa selfefficacy, strategi tugas, dan evaluasi diri adalah strategi belajar mandiri yang diatur sendiri oleh mahasiswa. Fase kinerja dan fase refleksi diri memainkan peran penting dalam proses pembelajaran yang diatur secara mandiri.

Dari uraian pembahasan, dapat digarisbawahi bahwa kemandirian belajar mahasiswa yang tergolong sedang perlu ditingkatkan dengan strategi pengaturan belajar secara tepat. Upaya peningkatan kemandirian belajar perlu mempertimbangkan temuan penelitian berdasarkan aspek-aspek dan indikator-indikator dalam kemandirian belajar. Perbedaan kemandirian belajar mahasiswa ditinjau dari usia dan jenis kelamin sesuai dengan prinsip perbedaan individu (individual differences) dan memberikan implikasi bahwa setiap mahasiswa memiliki cara dan gaya yang berbeda dalam mengembangkan kemandirian belajarnya masing-masing.

\section{PENUTUP}

Hasil penelitian ditemukan bahwa sebagian besar mahasiswa program studi bimbingan dan konseling FIP UNY memiliki kemandirian belajar pada kategori sedang. Kemandirian belajar ditinjau dari jenis kelamin menunjukkan bahwa kemandirian belajar mahasiswa perempuan lebih tinggi dibandingkan kemandirian belajar mahasiswa laki-laki. Hasil penelitian berdasarkan usia diketahui bahwa kemandirian belajar mahasiswa usia muda lebih tinggi dibandingkan kemandirian belajar mahasiswa usia lebih tua. Hasil penelitian kemandirian belajar ditinjau dari aspekaspek kemandirian belajar ditemukan 
bahwa aspek motivasi lebih banyak mempengaruhi kemandirian belajar mahasiswa program studi bimbingan dan konseling FIP UNY jika dibandingkan dengan aspek kemandirian belajar yang lain, yaitu aspek perilaku dan aspek kognitif. Temuan penelitian yang terakhir diketahui bahwa hanya aspek motivasi pada kemandirian belajar yang memiliki nilai rata-rata tinggi pada indikatornya. Keseluruhan hasil penelitian berupa profil kemandirian belajar memberikan implikasi bahwa mahasiswa sangat perlu untuk meningkatkan kemandirian belajarnya dikarenakan berpengaruh pada prestasi belajar dan kesuksesan akademik selama pembelajaran di universitas. Hasil penelitian ini memberikan rekomendasi kepada pihak universitas untuk mendukung peningkatan kemandirian belajar mahasiswa. Model-model program universitas terkait strategi pengaturan diri dalam belajar menjadi penting untuk dirancang dan diimplementasikan demi menunjang peningkatan kemandirian belajar mahasiswa.

\section{DAFTAR PUSTAKA}

Abun, D. \& Magallanes, T. (2018). Academic self-regulation of STEM of senior high school students of divine word colleges in region I, Philippines and their academic performance. Texila International Journal of Academic Research. Volume 5, Issue 1, May 2018.

Aydin, S., Harputlu, L., Çelik, Ş.S., Uştuk. Ö., \& Güzel, S. (2017). Age, gender and grade effect on foreign Language anxiety among children. TEFLIN Journal, Volume 28, Number 2, July 2017.

DOI: http://dx.doi.org/10.15639/teflinjour nal.v28i2/133-154.

Chitashvili, N. (2007). The concept of autonomy in second language learning. Georgian Electronic Scientific Journal: Education Science and Psychology, Vol. 2(11), 2007.

Corbin, A. (2017). Assessing differences in learning styles: age, gender and academic performance at the tertiary level in the Caribbean. Caribbean Teaching Scholar. Vol. 7, April 2017, 67-91.

Ellis, J.M., \& Helaire, L.J. (2018). The effects of adolescent self-regulated learning on engagement in a college access program: an exploratory study. AERA Open. January-March 2018, Vol. 4, No. 1, pp. 1-17. DOI: 10.1177/2332858418756051.@The Author(s) 2018. http://journals.sagepub.com/home/er o.

Fauzi, A. \& Widjajanti, D.B. (2018). Selfregulated learning: the effect on student's mathematics achievement. Journal of Physics: Conference Series. IOP Conf. Series. 1097 (2018) 012139 doi :10.1088/17426596/1097/1/012139.

Harding, S.M. (2018). Self-regulated learning in the classroom. As part of the realising the potential of Australia's high capacity students linkage project. Melbourne Graduate School of Education. Assessment Research Centre. https://www.researchgate.net/publica tion/327051231.

Johnson, G.M. \& Davies, S.M. (2014). Self-regulated learning in digital environments: theory, research, praxis. British Journal of Research. BJR[1][2][2014]068-080. ISSN: 2394-3718. www.britishjr.org.

Kalendaa, J. \& Vávrováa, S. (2016). Selfregulated learning in students of helping professions. Procedia Social and Behavioral Sciences 217 (2016) 282-292. Future Academy®'s Multidisciplinary Conference.

Li, J., Ye, H., Tang, Y., Zhou, Z., \& Hu, X. (2018). What are the effects of selfregulation phases and strategies for Chinese students? A meta-analysis of two decades research of the association between self-regulation and academic performance. Frontiers in Psychology, 9, Article ID 2434. 
http://dx.doi.org/10.3389/fpsyg.2018 .02434 .

Mahmoodi, M.H., Kalantari, B., \& Ghaslani, R. (2014. Self-Regulated Learning (SRL), motivation and language achievement of Iranian EFL learners. Procedia-Social and Behavioral Sciences. Volume 98, 6 May 2014, Pages 1062-1068. https://doi.org/10.1016/j.sbspro.2014 03.517.

Matthews, J.S., Cameron, C.E., \& Moriison, F.J. (2009). Early gender differences in self-regulation and academic achievement. Journal of Educational Psychology 101(3):689704. August 2009. DOI: 10.1037/a0014240.

Mohammadi, S., Mobarhan, M.G., Mohammadi, M., \& Ferns, G. A.A. (2015). Age and gender as determinants of learning style among medical students. British Journal of Medicine \& Medical Research. 7(4): 292-298, 2015, Article no.BJMMR.2015.335. ISSN: 22310614. Sciencedomain international. www.sciencedomain.org.

Moos, D.C. \& Ringdal, A. (2012). Selfregulated learning in the classroom: a literature review on the teacher's role. Review Article. Education Research International. Volume 2012, Article ID 423284, 15 pages. doi:10.1155/2012/423284. Hindawi Publishing Corporation.

Sebesta, A.J. \& Speth, E.B. (2017). How should i study for the exam? selfregulated learning strategies and achievement in introductory Biology. CBE_Life Sciences Education. 16:ar 30, 1-12, Summer 2017.

Studenska, A. (2011). Educational level, gender and foreign language learning self-regulation difficulty. Procedia Social and Behavioral Sciences 29 (2011) 1349 - 1358 .International Conference on Education and Educational Psychology (ICEEPSY 2011).
Usher, E.L. \& Pajares, F. (2008). Selfefficacy for self-regulated learning: a validation study. Educational and Psychological Mesurement. Volume: 68 issue: 3, page(s): 443-463, published: June 1, 2008.

Valle, A., Núñez, J.C., Cabanach, R.G., González-Pienda, J.A., Rodríguez, S., Rosário, P., Cerezo, R., MuñozCadavid, M.A. (2008). Self-regulated profiles and academic achievement. Psicothema 2008. Vol. 20, no. 4, pp. 724-731. www.psicothema.com.

Weis, M., Heikamp, T., \& Tromsdorff, G. (2013). Gender differences in school achievement: The role of selfregulation. Front. Psychol., 17 July 2013

https://doi.org/10.3389/fpsyg.2013.0 0442.

Zimmerman, Barry J. (1989). Selfregulated learning and academic achievement: theory, research, and practice. Bozeman, Montana: Publishers Service. 